\title{
Cervical Glandular Intraepithelial Neoplasia
}

National Cancer Institute

\section{Source}

National Cancer Institute. Cervical Glandular Intraepithelial Neoplasia. NCI Thesaurus.

Code C7673.

A neoplastic process that affects the glandular epithelial cells of the cervix. There is no evidence of invasion. It is classified as low or high grade. 